\title{
PENGARUH GAYA BELAJAR SISWA TERHADAP HASIL BELAJAR FISIKA SMA PGRI MAROS
}

\author{
Fitriani Kadir, Imam Permana, Nurul Qalby \\ Universitas Muslim Maros, UIN Alauddin Makassar \\ fktria85@umma.ac.id
}

\begin{abstract}
The Effect Of Learning Styles Of Students On The Result Of Physics Of Sma Pgri Maros. The purpose of this study was to determine the effect of visual learning styles on physics learning outcomes at PGRI Maros High School, to determine the influence of auditory learning styles on physics learning outcomes at PGRI Maros High School, and to determine the effect of kinesthetic learning styles on physics learning outcomes at Marri PGRI High School. This study is an ex post facto study, meaning that research on variables that occurred before the research was conducted. The research was carried out by looking back to find out the factors that caused the incident without giving treatment or manipulating the variables studied. The results showed that of 41 students at PGRI Maros high school who filled out the learning style questionnaire there were 19 students $(46.34 \%)$ who had a visual learning style tendency, there were 19 students $(46.34 \%)$ who had an auditorial learning style tendency, and there were 3 students $(7.31 \%)$ which tends to kinesthetic learning style. This shows that the dominant learning style possessed by Xmia class students at SMA PGRI Maros is visual and auditory learning styles with a percentage of $46.34 \%$ and $46.34 \%$. There is a positive and significant influence of visual learning style on physics learning outcomes. The contribution of visual learning styles to physics learning outcomes at PGRI Maros High School with a visual percentage of $44.34 \%$ and the number of frequencies 19 . This means that the higher the visual learning style, the better the physics learning outcomes will be. So students who love to read and are not bothered by noise will be able to improve learning outcomes in physics.
\end{abstract}

Keywords: visual, auditory, kinesthetic

\begin{abstract}
Abstrak: Pengaruh Gaya Belajar Siswa Terhadap Hasil Belajar Fisika SMA PGRI Maros. Tujuan dari penelitian ini adalah mengetahui pengaruh gaya belajar visual terhadap hasil belajar fisika di SMA PGRI Maros dan pengaruh gaya belajar auditori terhadap hasil belajar fisika di PGRI SMA Maros serta mengetahui pengaruh pembelajaran kinestetik. gaya pada hasil belajar fisika di SMA PGRI Maros. Penelitian ini merupakan penelitian ex post facto. Hasil penelitian menunjukkan bahwa dari 41 siswa di SMA PGRI Maros yang mengisi angket gaya belajar ada 19 siswa $(46,34 \%)$ yang memiliki kecenderungan gaya belajar visual, ada 19 siswa $(46,34 \%)$ yang memiliki kecenderungan gaya belajar auditorial , dan ada 3 siswa $(7,31 \%)$ yang cenderung gaya belajar kinestetik. Hal ini menunjukkan bahwa gaya belajar dominan yang dimiliki oleh siswa kelas
\end{abstract}


Xmia di SMA PGRI Maros adalah gaya belajar visual dan auditori dengan persentase $46,34 \%$ dan $46,34 \%$. Ada pengaruh positif dan signifikan gaya belajar visual terhadap hasil belajar fisika. Kontribusi gaya belajar visual terhadap hasil belajar fisika di PGRI Maros High School dengan persentase visual 44,34\% dan jumlah frekuensi 19. Ini berarti bahwa semakin tinggi gaya belajar visual, semakin baik hasil belajar fisika akan. Jadi siswa yang suka membaca dan tidak terganggu oleh kebisingan akan dapat meningkatkan hasil belajar dalam fisika.

Kata kunci: visual, auditori, kinestetik

Gaya belajar adalah cara yang konsisten yang dilakukan oleh seorang peserta didik dalam menangkap stimulus atau informasi, cara mengingat, berpikir, dan memecahkan soal. Tidak semua orang mengikuti cara yang sama. Masing-masing menunjukkan perbedaan, namun para peneliti dapat menggolong-golongkannya. Gaya belajar ini berkaitan erat dengan pribadi seseorang, yang tentu dipengaruhi oleh pendidikan dan riwayat perkembangannya (Nasution, 2010:94).

Bagaimana sebuah informasi dapat diterima dengan baik oleh peserta didik. Jadi gaya belajar peserta didik adalah hal yang sangat berkaitan, saling mendukung satu dengan yang lain, dan sangat menentukan keberhasilan suatu proses belajar. Gaya belajar ini merupakan salah satu aspek yang perlu mendapat perhatian. Gaya belajar merupakan cara termudah yang dimiliki oleh individu dalam menyerap, mengatur dan mengolah informasi yang diterima. Gaya belajar yang sesuai adalah kunci keberhasilan seseorang dalam belajar. Oleh karena itu, dalam kegiatan belajar, siswa sangat perlu dibantu dan diarahkan untuk mengenali gaya belajar yang sesuai dengan dirinya sehingga tujuan pembelajaran dapat dicapai secara efektif.

Sebagai seorang pendidik harus mampu mengakomodir semua gaya belajar siswa. Secara umum gaya belajar terbagi menjadi 3, yang biasa dikenal dengan VAK (Visual, Auditorial dan Kinestetik). Siswa dengan gaya belajar visual biasanya mudah untuk menerima informasi atau pelajaran dengan visualisasi dalam bentuk gambar, tabel, diagram, grafik, peta pikiran, goresan atau simbol-simbol. Untuk siswa yang memiliki gaya belajar auditorial senang sekali jika pembelajaran dilakukan dalam bentuk cerita, lagu, syair atau senandung. Sedangkan siswa dengan gaya belajar kinestetik akan mudah untuk menerima pelajaran yang diiringi dengan aktivitas motorik, seperti dalam konsep penerapan/percobaan, drama dan gerak (Gora, 2010: 93).

\section{METODE}

Penelitian ini termasuk penelitian ex post facto, artinya penelitian tentang variabel yang kejadiannya sudah terjadi sebelum penelitian dilaksanakan (Arikunto, 2010: 17). Penelitian dilakukan dengan merunut ke belakang untuk mengetahui faktor-faktor yang menimbulkan kejadian tersebut tanpa memberikan perlakuan atau memanipulasi variabel yang diteliti.

Penelitian ini merupakan penelitian kuantitatifdengan analisis regresi linear sederhana, karena penelitianyang dilakukan ditujukan untuk mengambil informasi langsung yang ada dilapangan mengenai gaya belajar siswa pada mata pelajaran fisika. VariabelX dalam penelitian ini yaitu gaya belajar yang terdiri dari Visual, Auditorialdan Kinestetik. Variabel Y dalam penelitian ini yaitu nilai raport semester 1 diraih siswa pada mata pelajaran fisika. Penelitian inimendeskripsikan hasil identifikasi mengenai gaya belajar siswa kelas $\mathrm{X}$ mia padapembelajaran fisika kemudian menghitung frekuensi siswa yang memilikigaya belajar visual, auditorial atau kinestetik. Pengambilan data dalampenelitian ini menggunakan angket siswa.

\section{HASIL DAN PEMBAHASAN}

Berdasarkan hasil penelitian yang dilakukan disekolah SMA PGRI Maros pada kelas X yang berjumlah 41 orang. Maka peneliti dapat mengumpulkan data melalui angket yang diisi oleh siswa SMA PGRI Maros, kemudian diberikan masing-masing skor pada masingmasing item pertanyaan sehingga data-data 
tersebut dapat dianalisis secara deskriptif, setelah data tersebut telah dianalisis. Selanjutnya melihat skor tertinggi diantara tiga gaya belajar tersebut.

Berdasarkan jumlah skor tertinggi maka setiap siswa digolongkan apakah termasuk kedalam gaya belajar kinestetik, visual, atau auditorial. Hasil pengklasifikasian siswa berdasarkan gaya belajarnya dapat dilihat pada Tabel 4.1 berikut:

Tabel 1. Gaya Belajar Siswa SMA PGRI Maros

\begin{tabular}{ccc}
\hline No & Gaya Belajar & Jumlah Siswa \\
\hline 1 & Kinestetik & 3 \\
2 & Visual & 19 \\
3 & Auditorial & 19 \\
\hline & Total & $\mathbf{4 1}$ \\
\hline
\end{tabular}

Sumber : data sekunder hasil penelitian 2018

Berdasarkan tabel 1 terdapat 3 siswa dengan gaya belajar kinestetik, 19 siswa dengan gaya belajar visual dan 19 siswa dengan gaya belajar auditorial.
Apabila skor angket pada tabel 1 di kelompokkan, maka diperoleh distribusi frekuensi dan persentase pada table 2 berikut:

Tabel 2 frekuensi dan persentase skor angket gaya belajar siswa SMA PGRI Maros

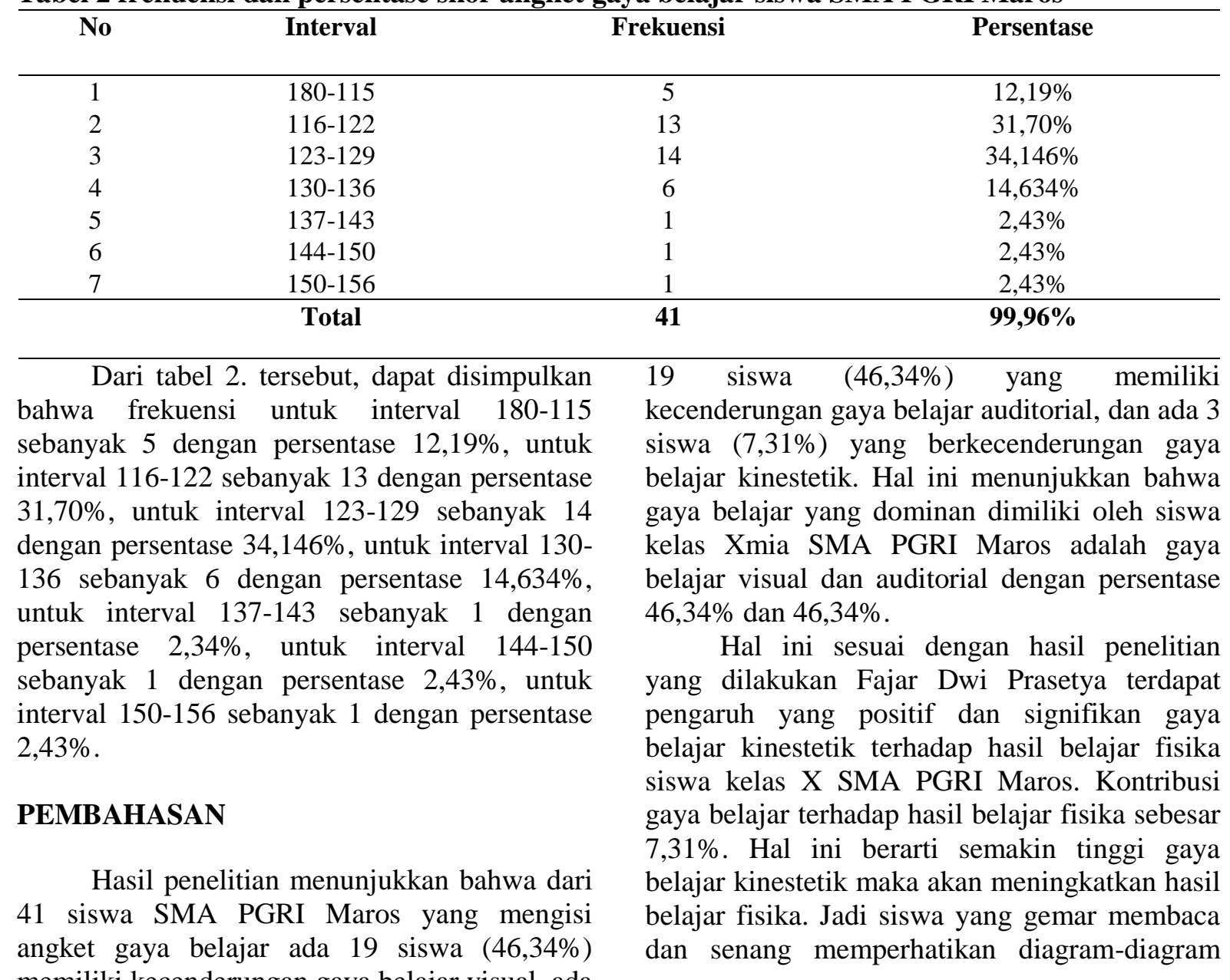


maupun video tentang fisika akan dapat meningkatkan hasil belajar fisika.

Hasil penelitian menunjukkan bahwa terdapat pengaruh yang signifikan antara gaya belajar dan hasil belajar. Hal ini dapat dilihat pada nilai signifikasi 0,00 lebih kecil dari kriteria signifikansi yakni 0,05 dan nilai determinasi gaya belajar yang memberikan kontribusi sebesar 9,7\%. Hal ini sesuai dengan penelitian yang dilakukan Fajar Dwi Prasetya. Terdapat pengaruh yang positif dan signifikan gaya beljar auditorial terhadap hasil belajar fisika siswa kelas X SMA PGRI Maros. Kontribusi gaya belajar auditorial terhadap hasil belajar fisika sebesar $46,34 \%$. Hal ini berarti semakin tinggi gaya belajar visual maka akan meningkatkan hasil belajar fisika. Jadi siswa yang senang mendengarkan penjelasan dari guru maupun teman akan mudah memahami pelajaran fisika sehingga dapat meningkatkan hasil belajarnya.

Terdapat pengaruh yang positif dan signifikan gaya belajar auditorial terhadap hasil belajar fisika siswa kelas X SMA PGRI Maros. Kontribusi gaya belajar auditorial terhadap hasil belajar fisika sebesar $46,34 \%$. Hal ini berarti semakin tinggi gaya belajar auditorial maka akan meningkatkan hasil belajar fisika. Siswa yang senang melakukan praktik mereka akan mendapatkan hasil belajar fisika yang baik, dimana dalam pembelajaran fisika banyak dilakukan praktikum.

Adapun kendala selama melaksanakan penelitian yaitu masih banyak siswa yang keluar masuk saat mengisi angket penelitian, selain itu kurangnya kesadaran siswa terkait kehadirannya di sekolah sehingga peneliti harus bolak-balik ke sekolah untuk membagikan angket bagi siswa yang belum mengisi angket tersebut.

\section{PENUTUP}

Berdasarkan hasil dan pembahasan penelitian yang dikemukakan, maka kesimpulan yang dapat dikemukakan dalam penelitian ini adalah sebagai berikut.

Terdapat pengaruh yang positif dan signifikan gaya belajar visual terhadap hasil belajar fisika. Kontribusi gaya belajar visual terhadap hasil belajar fisika SMA PGRI Maros dengan persentase visual $44,34 \%$ dan jumlah frekuensi 19. Hal ini berarti semakin tinggi gaya belajar visual maka akan meningkatkan hasil belajar fisika. Jadi siswa yang gemar membaca dan tidak terganggu oleh keributan akan dapat meningkatkan hasil belajar fisika.

Terdapat pengaruh yang positif dan signifikan gaya belajar auditorial terhadap hasil belajar fisika. Kontribusi gaya belajar auditorial terhadap hasil belajar fisika SMA PGRI sebesar persentase auditorial $44,34 \%$ dan jumlah frekuensi 19 dari 41 responden. Hal iniberarti semakin tinggi gaya belajar auditorial maka akan meningkatkan hasil belajar fisika. Jadi siswa yang senang mendengarkan penjelasan dari guru maupun teman akan mudah memahami pelajaran fisika sehingga dapat meningkatkan hasil belajarnya.

Terdapat pengaruh yang positif dan signifikan gaya belajar kinestetik terhadap hasil belajar fisika. Kontribusi gaya belajar kinestetik terhadap hasil belajar fisika SMA PGRI Maros sebesar dengan persentase kinestetik 7,31\% dan jumlah frekuensi 3. Hal ini berarti semakin tinggi gaya belajar kinestetik maka akan meningkatkan hasil belajar fisika. Siswa yang dapat duduk diam untuk waktu lama dan menghafal dengan cara berjalan dan melihat akan mendapatkan hasil belajar fisika yang baik, dimana kondisi siswa pada sekolah tersebut sering berkeliaran selama proses pembelajaran berlangsung.

\section{DAFTAR PUSTAKA}

Arikunto. 2010. Prosedur penelitian Suatu Pendekatan Praktik. Rineka Cipta,Jakarta. hal.120-174

DePorter, B dan M. Hernacky. 2005. Quantum Learning. Jakarta:Kaifa 356 hal

Dimyati. 2009. Belajar dan Pembelajaran. Jakarta: PT Rineka Cipta

Ghufron, N dan R. Risnawati. 2012. Gaya Belajar Kajian Teoretik. Yogyakarta: Pustaka Belajar.

Ghozali, Imam. 2006. Aplikasi Analisis Multivariate dengan program SPSS (Edisi $\mathrm{Ke} 4$ ). Semarang:Badan Penerbit Universitas Diponegoro.Kotler, Philip. 2001. Manajemen Pemasaran di Indonesia : Analisis

Gora, Wirastwan dan Sunarto. 2010. Pakematik: Strategi Pembelajaran Inovatif 
Berbasis TIK, Jakarta: ElexmediaKomputindo. Wulandari, R. 2011. Hubungan Gaya Belajar Dengan Prestasi BelajarMahasiswa Semester IV Program Study D IV Kebidanan Universitas SebelasMaret. Disertasi tidak dipublikasikan. Surakarta:Universitas Sebelas Maret.

Halim, A. 2012. Pengaruh Strategi Pembelajaran dan Gaya Belajar terhadap Hasil Belajar Fisika Siswa SMPN 2 Secanggang Kabupaten Langkat. PPS Unimed. Langkat. Jurnal. 18 hal

Hanifa. 2010. Bina Pustaka Sarwono Prawirohardjo. Jakarta:Ilmu KandunganYayasan

Mira Wulandari. 2014. Analisis Gaya Belajar Siswa dan Hubungannya dengan Hasil Belajar Fisika Siswa Kelas XI di SMA Negeri I Kota Jambi. Disertasi tidak dipublikasikan. Jambi: Universitas Jambi.

Nasution, S. 2010. Berbagai Pendekatan dalam Proses Belajar \& Mengajar. Jakarta:Bumi Aksara.

Nurochma, Rofa. 2012. Perbedaan Hasil Belajar dengan Penerapan Strategi Pembelajaran GuidedInquiry dan Demonstrasi Ditinjau dari Gaya Belajar Siswa Kelas VIII SMP Negeri 1 Jaten tahun Pelajaran 2011/2012. Jurnal Pendidikan Fisika Universitas Sebelas Maret.

Prasetya, Dwi Fajar. 2012. Pengaruh Gaya Belajar Terhadap Prestasi Belajar Mata Diklat Listrik Otomotif Siswa Kelas XI Teknik Perbaikan Bodi Otomotif SMKN 2 Depok Sleman. Disertasi tidak dipublikasikan. Yogyakarta: Universitas Negeri Yogyakarta

Qodriah, A. 2011. Hubungan Antara Gaya Belajar Dengan Hasil Belajar Mata Pelajaran Aqidah Akhlak Siswa Kelas IV MI Miftakhul Akhlaqiyah Bringin Ngaliyan Semarang Institut Agama Islam Walisongo. Diunduh di http://library.walisong o.ac.id/digilib/files/disk1/113/jtptiaingdlannieqodri-5602-1-093111142.pdf.

Rosida, A. 2009. Pengaruh Gaya Belajar Siswa Terhadap Prestasi Belajar Siswa Pendidikan Agama Islam Siswa SMA Negeri 5 Malang. UniversitasIslam Negeri (UIN). Malang. 123 hal
Rusman. 2012. Model-Model Pembelajaran. Depok: PT Rajagrafindo Persada

Slavin, R. E. 2008. Psikologi Pendidikan. Jakarta:PT Indeks 322 hal

Sugiyono. 2008. Metode Penelitian Kunatitatif Kualitatif dan R\&D. Bandung.

Sugiyono. 2015. Metode Penelitian Pendidikan (Pendekatan Kuantitatif. Kualitatif dan $R \& D$ ). Penerbit CV. Bandung: Alfabeta.

Suharsimi. 2002. Metodologi Penelitian. Jakarta: PT. Rineka Cipta.

Sulistyorini. 2009. Evaluasi Pendidikan Dalam Meningkatkan Mutu Pendidikan.Yogyakarta: Teras

Sumiati. 2007. Metode Pembelajaran Pendekatan Individual. Bandung: Rancaekek Kencana.

Supranto, J. 2004. Analisis Multivariat Arti dan Interpretasi. Jakarta: Rineka Cipta.

Susilowarno, dkk.2007. Fisika untuk SMA/MA kelas $X$. Jakarta: Grasindo

Taruh, Enos. 2003. Konsep Diri dan Motivasi Berprestasi dan Kaitannya DenganHasil Belajar. Jurnal Penelitian Pendidikan. Gorontalo: IKIP Negeri GorontaloAkbar rasyid, (2008), epilepsi: seri aku anak sehat, Jakarta: zikrul haki, Clegg brian, edisi.2, instant motivation, isbn: 9790150830:esensi

Widodo. 2006. Taksonomi Bloom dan Pengembangan Butir Soal. Jurnal Pendidikan Fisika, Volume 3, hal.18-9.

Wulandari, Fitria Eka. 2011. Pengembangan Media Pembelajaran Fisika SMP Berbasis Komputer Bahan Kajian Sistem Syaraf danSistem Indera pada Manusia. Jurnal Pedagogia, Volume 1, Nomor 1,hal. 99- 109. 